\title{
SONHOS DE UMA MESQUITA ICÔNICA: ENTRELAÇAMENTOS TEMPORAIS E ESPACIAIS EM UMA IGREJA CONVERTIDA DE AMSTERDÃ ${ }^{1}$
}

\author{
Daan Beekers ${ }^{2}$ \\ Pooyan Tamimi Arab
}

Resumo: Este artigo foca na criação de iconicidade através da arquitetura religiosa em Amsterdã, Holanda. Ao examinar a Mesquita de Fatih, abrigada em uma antiga igreja católica no centro da cidade, apresentamos de que maneiras os esforços para fazer desta uma mesquita icônica são moldados pelo terreno icônico da construção, pelo qual determinamos seu envolvimento com outros locais (religiosos e não religiosos) do passado e do presente. Esse campo icônico é caracterizado pelas cadeias de conversão que precederam a mesquita, legados materiais e discursivos de "ocultação" e interaçôes simbólicas contemporâneas com construçóes próximas, como a Igreja Ocidental. Ao desenvolver uma análise dos entrelaçamentos espaciais e temporais da Mesquita com o espaço urbano de Amsterdá, buscamos revitalizar uma abordagem diacrônica e relacional que vem sendo negligenciada, principalmente em estudos sociais-científicos de mesquitas no Ocidente. Não iremos analisar um único local de devoção em um momento específico na história, mas chamaremos atenção para as relaçóes entre o Islamismo e outras arquiteturas religiosas e para as maneiras com que as mesquitas interagem com amplas genealogias e geografias das religióes, não apenas por associação, mas também por conexôes concretas de relaçóes, política ou cultura material.

1 Traduzido por Tatiana Barbiero Frantz e Thierry de Lima Torres, sob a supervisão e revisão de tradução da Prof. ${ }^{a}$ Dr. ${ }^{a}$ Elizamari Becker (IL/UFRGS). Este texto foi originalmente publicado na revista Material Religion, em 2016. Agradecemos aos editores daquele periódico pela cessão para que fosse publicado em português.

2 Daan Beekers é pesquisador de pós-doutorado no Institute for Advanced Studies in the Humanities, University of Edinburgh. Contato: d.t.beekers@uu.nl

3 Pooyan é professor no departamento de filosofia e estudos de religiáo da Utrecht University. Contato: pooyan.tamimiarab@wereldculturen.nl

Debates do NER, Porto Alegre, ANo I9, N. 34, P. I83-222, Ago./Dez. 20 i 8 
Palavras-chave: Igrejas Convertidas; Entrelaçamento; Iconicidade; Campoicônico; Islã; Mesquitas; Arquitetura Religiosa; Holanda.

Abstract: This article focuses on the making of iconicity through religious architecture in Amsterdam, the Netherlands. Examining the Fatih Mosque housed in a former Catholic church in the city center, we show in what ways the efforts at making this mosque iconic are shaped by the building's iconic field, by which we denote its entanglement with other (religious and non-religious) sites in the past and the present. This iconic field is characterized by the conversion chains that preceded the mosque, material and discursive legacies of "hiddenness" and contemporary symbolic interactions with nearby sites such as the Western Church. By developing an analysis of the mosque's temporal and spatial entanglements in Amsterdam's urban space, we seek to revitalize a relational and diachronic approach that has suffered from neglect, particularly in social-scientific studies of mosques in the West. Rather than looking at a singular place of worship at a particular moment in time, we draw attention to the relations between Islamic and other religious architecture and to the ways in which this mosque intersects with broader genealogies and geographies of religion, not only by association but also by actual links in relationships, politics or material culture.

Keywords: Converted Churches; Entanglement; Iconicity; Iconic Field; Islam; Mosques; Religious Architecture; The Netherlands.

\section{INTRODUÇÃO}

Em 2002, uma pedra de uma das torres da antiga igreja católica The Sower caiu em meio a uma rua movimentada. A igreja, construída em 1929 e localizada no centro de Amsterdã, estava em ruínas. Havia vazamentos no telhado, mofo nas paredes e risco de desmoronamento de partes da torre, devido à madeira apodrecida. $\mathrm{O}$ que restou da comunidade católica já havia abandonado o edifício, e o mesmo foi vendido em 1971. Após ocupaçóes temporárias para diversos fins, ele foi comprado em 1981 por membros de uma comunidade muçulmana turca local. A partir de então, a 
The Sower foi chamada de Mesquita de Fatih e se tornou a maior mesquita de Amsterdã. Apesar do orgulho que a comunidade muçulmana sempre teve do edifício, agora ela também enfrentava a dificuldade em manter uma construçấo tão antiga. Como não tinha capital financeiro para restaurá-la, foram aconselhados a torná-la um monumento histórico oficial de Amsterdá. Se lograssem essa classificação, os proprietários poderiam solicitar assistência financeira do governo. Em 2001, o valor histórico e monumental do edifício foi reconhecido pela cidade, mas a comunidade responsável pela mesquita ainda náo havia conseguido reparar a torre danificada. Quando a pedra caiu, o conselho da mesquita autorizou uma restauraçáo de grande escala no edifício, financiada com a renda de locação da mesquita e contribuiçôes da comunidade e do município.

O projeto de restauração reanimou a ambição adormecida de alguns líderes da mesquita: construir uma entrada mais visível para o local. Quando a igreja foi convertida em mesquita, a antiga entrada foi fechada e substituída por um mirabe, indicando a direção da oração para novos muçulmanos. A extinta entrada da igreja deu lugar a lojas, e uma pequena entrada discreta para a mesquita foi criada na lateral. $\mathrm{O}$ edifício não estava sinalizado como uma mesquita, exceto pelas cruzes que foram substituídas por discretas luas crescentes nas torres e uma pequena placa ao lado da porta com o inscrito "Fatih Camii Amsterdam" (camii é mesquita em turco). Apesar de grande parte da comunidade parecer satisfeita com essa solução, durante a restauraçáo surgiram novos líderes na comunidade, em geral membros mais jovens, que acreditavam profundamente que sua mesquita deveria ter mais reconhecimento e visibilidade. Eles perceberam que a iconicidade monumental do edifício como uma igreja (construída na época da emancipação católica) não apresentava a presença proeminente da mesquita que desejavam. Eles já haviam começado a interagir com o público não-muçulmano, organizando visitas guiadas pela mesquita e participando de iniciativas artísticas locais, além de outras formas de divulgaçáo. Consideravam que a aparência "oculta" da mesquita náo correspondia ao papel público que previam para ela, e que ela já assumia. Na sua visão, a Mesquita de Fatih deveria ter uma 
presença proeminente, visível e reconhecida na cidade, que se igualaria, ou ao menos se aproximaria, do patamar icônico de outras construçóes da regiáo, como a monumental Igreja Ocidental, a Casa de Anne Frank e o Homomonumento (Figura 1).

Figura 1: A Mesquita de Fatih e, ao fundo, a Igreja Ocidental

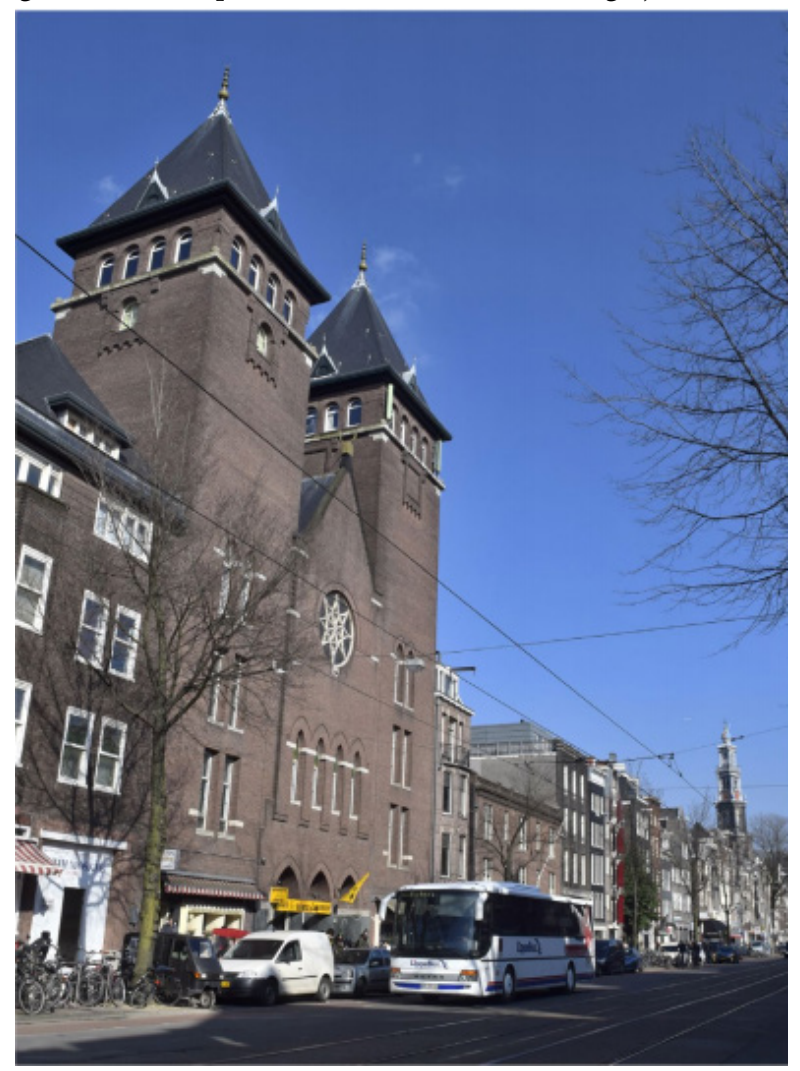

Nota-se a porta branca provisória à esquerda, colocada durante a construçáo da nova entrada. Fotografado por: Pooyan Tamimi Arab em 27 de fevereiro de 2016.

Neste artigo, examinamos esses esforços, que nomeamos "criação de iconicidade", entre os líderes da Mesquita de Fatih. Empregamos o termo "ícone" não somente no sentido coloquial de símbolo conceitual ou representativo 
(como em "marco icônico"), mas também no sentido analítico de formas materiais sensoriais que concentram significados e emoçóes religiosas específicas (Bartmanski; Alexander, 2012, p. 2). De acordo com esses dois significados, os líderes da mesquita desejavam, por um lado, o reconhecimento de seu edifício como "A" mesquita a ser vista no centro histórico de Amsterdá. Por outro, queriam que o edifício constituísse um sinal irrefutável do lugar de direito do islamismo na esfera pública holandesa. Argumentamos que estes esforços para criar iconicidade devem ser entendidos à luz não somente do início da construção consciente de mesquitas na Europa Ocidental (por exemplo, Kuppinger, 2014; Tamimi Arab, 2013), mas também do que denominamos campo icônico em que a mesquita está inserida. Este campo icônico inclui tanto o legado material e discursivo do edifício da igreja em que a mesquita está situada quanto a distribuição de construçóes icônicas com as quais os membros da comunidade muçulmana se identificam. Ou seja, investigamos como a criação de iconicidade está condicionada aos entrelaçamentos espaciais e temporais da mesquita no espaço urbano de Amsterdã. O caso da Mesquita de Fatih auxilia na abertura de novas possibilidades para pesquisa em lugares de devoção, em geral, e em mesquitas, em particular. Estudos científicos sociais na área tendem a focar em locais peculiares de um período específico negligenciando, com isso, a natureza interativa da arquitetura religiosa, isto é, as formas em que lugares de devoção são costumeiramente entremeados com outras construçôes religiosas e não-religiosas em um espaço geográfico específico, no passado e no presente. Apesar de pesquisas anteriores terem enfatizado questóes de espaço nas análises de religião urbana (por exemplo Becci; Burchardt; Casanova, 2013; Knott, 2005; Tweed, 2006), nós sugerimos que o conceito de campo icônico desenvolvido dentro do projeto de pesquisa Religiáo Icônica auxilia no embasamento de uma perspectiva relacional que vem sendo amplamente desconsiderada. Chamamos de "campo icônico" a distribuição e a interação entre locais icônicos e edifícios, que formatam e co-constituem um espaço específico no passado e no presente. Nossa perspectiva relacional e interativa dos lugares religiosos é baseada no trabalho de Robert Hayden, e seus associados, sobre espaços sagrados 
utilizados por diferentes comunidades religiosas ao longo do tempo em Anatólia, Portugal e Macedônia, pós Império Otomano (Hayden; Walker, 2013; Tanyeri-Erdemir; Hayden; Erdemir, 2014). Esses pesquisadores, ao criticar o foco atual em construçóes religiosas isoladas, acreditam que a devida atenção deva ser direcionada ao que chamam de "AAA", se referindo as maneiras em que diferentes comunidades religiosas e suas manifestações físicas se intersectam em um espaço geográfico específico e ao longo do tempo. A afirmação de que a arquitetura deve ser entendida sob uma perspectiva simbólica e interacionista não é nova. Entretanto, ao utilizar o conceito de campo icônico, desejamos revitalizar uma perspectiva relacional que é negligenciada principalmente em estudos científicos-sociais de mesquitas no Oeste. $\mathrm{O}$ foco da ampla gama de trabalhos sobre mesquitas tem sido em diversos aspectos, no processo de construção, na história institucional e na administraçáo (por exemplo, Maussen, 2009; Schmitt, 2003), na análise estilística (por exemplo, Dechau, 2009; Roose, 2009; Verkaaik, 2012), na crítica estilística (por exemplo, Erkoçu; Bugdací, 2009; Welzbacher, 2008), e na distribuição geográfica e socioeconômica nas cidades (por exemplo, Kuppinger, 2010). Mínima atenção tem sido dada às maneiras com que as mesquitas, nas cidades da Europa Ocidental, estão entrelaçadas com histórias religiosas locais e com outras construçôes, religiosas ou não.

Nós acreditamos que essa negligência é causada não somente pelo foco analítico nos edifícios em si, mas também por uma tendência acadêmica de separar as "minorias muçulmanas" de outras religióes e grupos culturais (Cf. Beekers, 2015). Isso contribui para um desdém das interações entre o islamismo e outras arquiteturas religiosas, assim como das maneiras com que as mesquitas são submetidas a modalidades políticas e sociais antigas para lidar com igrejas e sinagogas na esfera pública. Por contraste, estamos interessados no modo com que debates e práticas atuais acerca das mesquitas se intersectam com amplas genealogias e geografias das religióes, não apenas por associação, mas também por conexóes reais em relacionamentos, políticas e material cultural. Usamos como base, e buscamos aumentar, o pequeno número de estudos existentes que comparam os processos contemporâneos 
de construçóes de mesquita na Europa com precedentes históricos de edifícios de igreja (por exemplo, Sunier, 2009), assim como o trabalho recente sobre Londres, que examinou as conexôes diacrônicas e inter-religiosas que moldaram a vida religiosa e a arquitetura daquela cidade (Dodsworth; Vacchelli; Watson, 2013; Kershen; Vaughan, 2013).

Nos baseamos nos arquivos históricos e pesquisas teóricas sobre a história da Mesquita de Fatih e também em trabalhos de campo etnográficos realizados no local desde $2012^{4}$ para, primeiramente, explorar como as aspiraçóes icônicas atualmente manifestadas na comunidade da Mesquita de Fatih estão conectadas com a história deste edifício e com a cadeia de conversóes a qual foi submetido. Também mostramos que essas aspiraçóes estão ligadas ao gênero discursivo destas casas de devoção "ocultas", cuja raiz encontra-se na história das igrejas clandestinas da República Unida dos Países Baixos (entre 1588 e 1795) e tem sido apropriado em discussóes sobre mesquitas na Holanda. Em seguida, observamos como nos anos 2000 líderes da mesquita começaram a buscar meios pelos quais ela pudesse ser notada visualmente e reconhecida como "A" mesquita do centro histórico de Amsterdã, tanto por muçulmanos quanto por não-muçulmanos, em um primeiro momento por habitantes locais, mas logo atraindo visitantes nacionais e também internacionais. Finalizamos com a criaçáo de uma entrada islâmica nova e mais visível para a mesquita, que ainda estava emconstrução durante a elaboração deste artigo. Demonstramos que a busca por iconicidade implicou um processo duplo de atrair as pessoas e de "surgir" como uma mesquita da cidade, e no qual os líderes da mesquita explicitamente se identificaram com outras construçôes da região, religiosas ou não. Os anseios por iconicidade que observamos entre os membros da

4 Pooyan Tamimi Arab iniciou sua pesquisa etnográfica na Mesquita de Fatih em junho de 2012, por conta da sua pesquisa de doutorado sobre convocaçóes amplificadas para a oração (Tamimi Arab, no prelo). Vive nas imediaçóes da mesquita desde 2013. Daan Beekers conduziu um trabalho de campo na Mesquita de Fatih, incluindo vizinhos e visitantes, por conta do seu projeto de pesquisa Religiáo Icônica, que existe desde setembro de 2014 .

Debates do NER, Porto Alegre, ANo I9, N. 34, P. I83-222, Ago./Dez. 20 i 8 
comunidade da Mesquita de Fatih, em nossa visão, não fazem parte, de forma autoevidente, da maneira com que os praticantes religiosos abordam seus edifícios. Na verdade, como mostraremos, a criação de iconicidade na Mesquita de Fatih foi marcada por discordâncias entre diferentes grupos dentro da comunidade, especialmente entre geraçóes jovens e velhas, em relação necessidade de uma entrada nova e mais visível. Ficará claro que o desejo por uma mesquita icônica entre os jovens parece ser influenciada por sua ambição de ter seu lugar como muçulmanos reconhecido na sociedade holandesa, diante das práticas e discursos predominantes de exclusão. O foco deste artigo, entretanto, não está nesses debates intergeracionais nem nas experiências de exclusão dentro da comunidade muçulmana, pois ambos os assuntos já receberam muita atenção acadêmica. Preferimos nos concentrar em exibir o campo icônico onde os esforços em tornar icônica a Mesquita de Fatih estáo enraizados e, assim, demonstrar que a vida social da mesquita não está isolada da cultura local, mas entrelaçada com a história e topografia da cidade.

\section{CADEIAS DE CONVERSÃO}

A antiga igreja jesuíta, onde a Mesquita de Fatih está situada, está localizada em Rozengracht, uma rua ampla e movimentada que conecta a parte Ocidental da cidade ao distrito do canal, que desemboca na majestosa Igreja Ocidental e na Casa Anne Frank, um dos pontos turísticos mais badalados de Amsterdã. A igreja, devotada a Santo Inácio e popularmente conhecida como De Zaaier (The Sower), foi construída em 1929 pelo importante arquiteto de igrejas H. W. Valk. Sua vida útil como local de devoção católica só durou quatro décadas. A igreja fechou em 1971, e acabou sendo utilizada como loja de tapetes e de instrumentos musicais. Foi comprada por uma comunidade muçulmana turco-holandesa em 1981 e inaugurada como uma mesquita em 1982. O reaproveitamento da The Sower foi um dos primeiros exemplos de reutilização de igrejas que se espalhou pela Holanda. 
Só em Amsterdã, existem cerca de cinquenta igrejas (e outras construções cristâs) que foram convertidas para usos religiosos ou laicos (van Haarlem; Rotterdam; Belvedere, 2008, p. 194-197). Dessas, aproximadamente seis foram convertidas em mesquitas. ${ }^{5}$ Atualmente, entretanto, a reutilização de templos católicos como mesquitas se tornou menos provável, já que a prática foi revogada pela liderança holandesa da Igreja Católica e, geralmente, não é apoiada pelas igrejas Protestantes. ${ }^{6}$ A conversão disseminada de igrejas marca uma das mudanças mais importantes na presença material da religião em Amsterdã e na Holanda. Ironicamente, o rápido declínio das Igrejas operativas no contexto de uma população "não institucionalizada" deve ser compreendido à parte do cenário de extraordinário aumento na construção de igrejas durante o fim do século XIX e início do século XX, em parte fomentado pela emancipação dos Católicos. Quando a República Holandesa foi criada, no final do século XVI, a Igreja Reformada da Holanda (Calvinista) recebeu a posição de Igreja pública, sendo financiada pelo Estado e por autoridades civis. Manifestaçóes católicas de fé foram reprimidas e a infraestrutura organizacional do catolicismo foi desfeita (Israel, 1995, p. 361-367). Por muito tempo, as comunidades católicas e as calvinistas protestantes foram proibidas de erigir igrejas, tendo que recorrer ao que hoje é chamado de schuilkerken, igrejas clandestinas "ocultas", mas toleradas. A influência das forças revolucionárias francesas e a queda concomitante da República Holandesa, em 1795, trouxe liberdade religiosa aos católicos que, novamente, puderam construir igrejas. E o fizeram, principalmente após

5 Inventarisatie Kerkelijke Gebouwen in Nederland (Inventário dos edificios de igreja da Holanda), Historisch Documentatiecentrum voor het Nederlands Protestantisme (1800-heden), VU University Amsterdam. Disponível em: <http://www.hdc.vu.nl/nl/ online-infor-matie/ikgn/index.aspx>. Acesso em: 27 nov. 2015.

6 Veja os documentos políticos "Het kerkgebouw als getuige van de christelijke traditie" (Os edifícios de Igreja como testemunhas da tradição Cristã), publicado em 2009 pela Nederlandse Bisschoppenconferentie; e "Een protestantse visie op het kerkgebouw: Met een praktisch theologisch oormerk" (Uma visão protestante acerca do edifício de igreja: sob uma perspectiva teológico-prática, publicado em 2009 pelo Protestante Kerk da Holanda.

Debates do NER, Porto Alegre, ANo I9, N. 34, P. I83-222, Ago./Dez. 20 i 8 
o restabelecimento da hierarquia episcopal, em 1853, com uma revanche (Van Eijnatten; van Lieburg, 2005, p. 279-282). A Igreja The Sower é um produto dessa emancipação católica.

A história da comunidade desta igreja remonta a 1663, quando jesuítas fundaram uma igreja clandestina no sótão de uma casa chamada De Zaaier, "The Sower" (O Semeador), em Keizersgracht. Em 1837, a paróquia erigiu um novo templo construído para este fim no mesmo local, substituindo o clandestino (Von der Dunk, 2001). Depois, quando a paróquia decidiu ter um local sagrado mais centralizado, foi comprado um edifício em Rozengracht, em 1899. Esse edifício, chamado de Constantia, havia sido construído em 1890 pelos socialistas do Sociaal-Democratische Bond (Liga Social Democrática) como sua sede. Esse local é onde o famoso líder do partido, Ferdinand Domela Nieuwenhuis, ministro protestante que havia se tornado anarquista, costumava fazer os seus discursos (Figura 2). A venda de Constantia para os jesuítas ocorreu por meio de um agente intermediário. Os socialistas ficaram táo espantados ao descobrir quem eram os novos proprietários que se recusaram a entregar as chaves. Ainda assim, os religiosos conseguiram tomar posse do edifício e o converteram em uma igreja, que denominaram Capela de Săo José (ver Figura 3, Van Dael, 2014, p. 226). 
Figura 2: A última reunião dos socialistas no seu edifício, Constantia, com Ferdinand Domela Nieuwenhuis atrás do púlpito

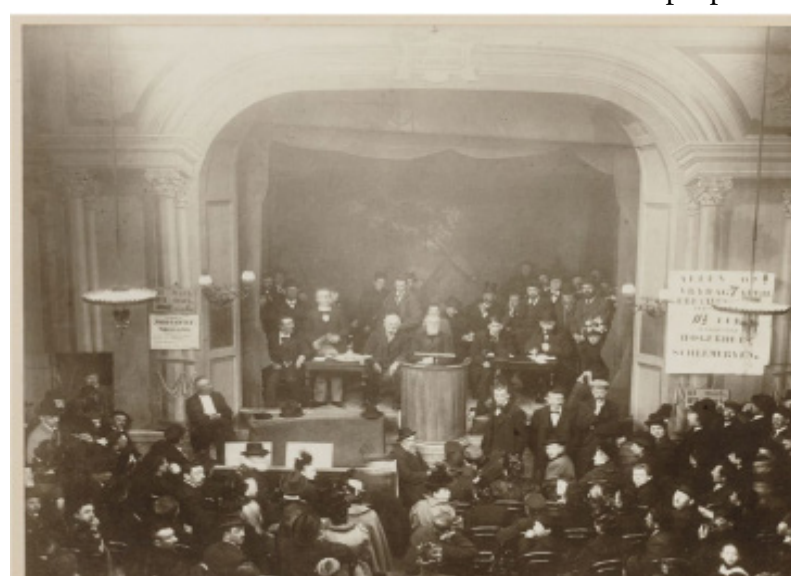

Fonte: Arquivo Municipal de Amsterdã, 16 de abril de 1899.

Figura 3: A Capela de São José no edifício anteriormente conhecido como Constantia

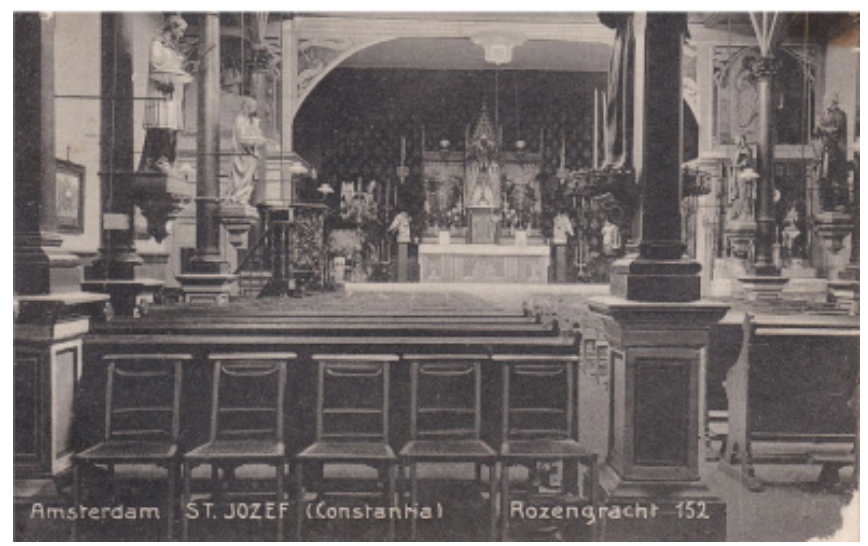

Cartão postal de meados da década de 20, publicado por Brinio em Roterdã e enviado em 26 de dezembro de 1928.

Fonte: Arquivo Fotográfico de Ad Tiggeler. 
Em 1906, o crítico de arte e católico Jan Kalf escreveu que mudanças tão pequenas haviam sido feitas no edifício que não se poderia realmente distinguir uma arquitetura eclesiástica: "ainda se parece com a câmara dos socialistas, mas ao invés do palco há um altar e, ao invés dos gabinetes, há uma sacristia... Na fachada, existe apenas uma grande cruz de ferro no topo, identificando o propósito do edifício" (citação de Van Dael, 2014, p. 226). $\mathrm{Na}$ década de 20, foi decidido abandonar a The Sower em Keizersgracht, pois cada vez mais pessoas estavam deixando o distrito do canal, e construir uma nova igreja no local da Capela de São José, em Rozengracht. Esse novo edifício paroquial, uma igreja neo-românica com duas grandes torres, adotou o nome de uma antiga igreja clandestina: The Sower. Nesse local, ao período inicial de florescimento da paróquia (Figura 4), logo seguiu-se um período de gradativo declínio, depois da Segunda Guerra Mundial.

Antes de adquirir a The Sower, a comunidade da Mesquita de Fatih esteve localizada, desde 1977, em outra antiga igreja, na De Heilige Stede, The Holy Stead (A Santa Ceia), que data de 1347. Atualmente, esse edifício constitui uma atraçáo turística, o Amsterdam Dungeon (O Ordálio de Amsterdã).

Um oficial da diocese de Haarlem-Amsterdam, em entrevista com um dos autores, Daan Beekers, relatou que a Igreja Católica sempre havia resistido à reutilizaçáo dos edifícios de seus templos para Mesquitas. Ele considerava que a venda da The Sower aos muçulmanos somente fora possível por que, primeiro, havia sido transformada em uma loja de tapetes, o que descreveu como "estágio intermediário ilegal" (Figura 5). 
Figura 4: Interior da igreja católica The Sower durante missa solene, por volta de 1935

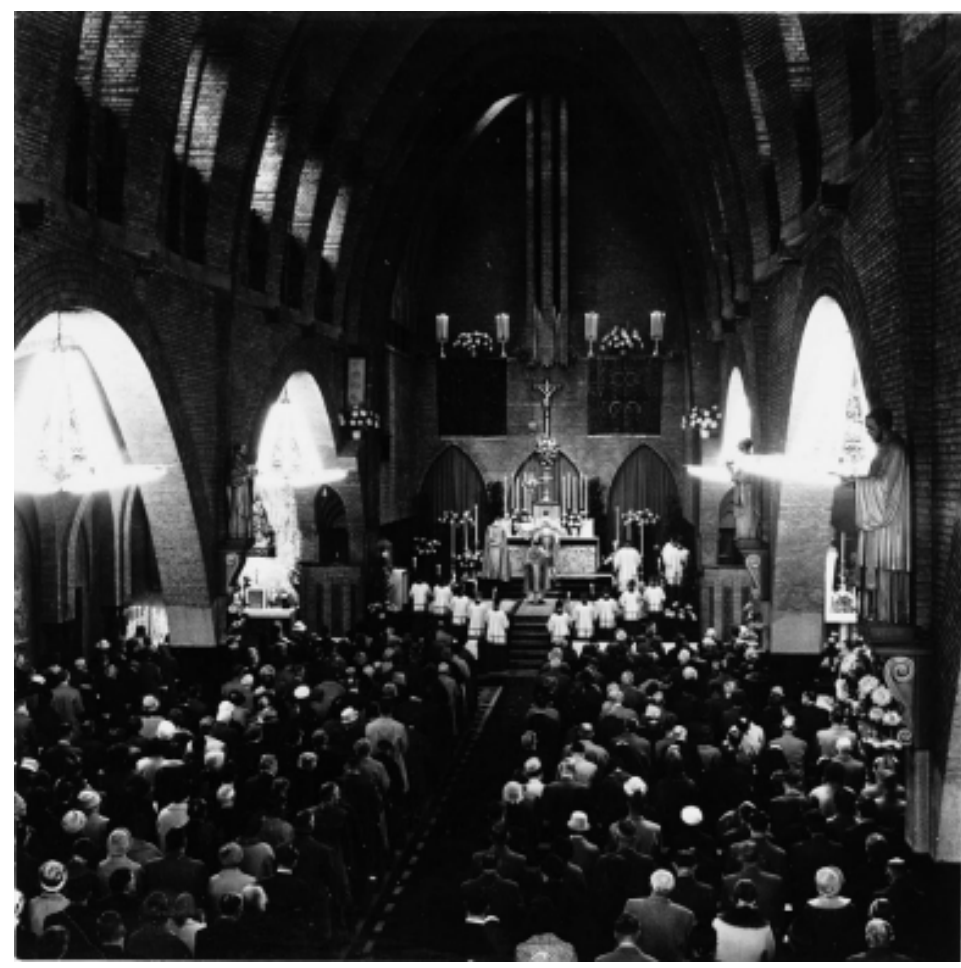

Fonte: Arquivo Municipal de Amsterdã. 
Figura 5: Loja de tapetes na antiga igreja The Sower

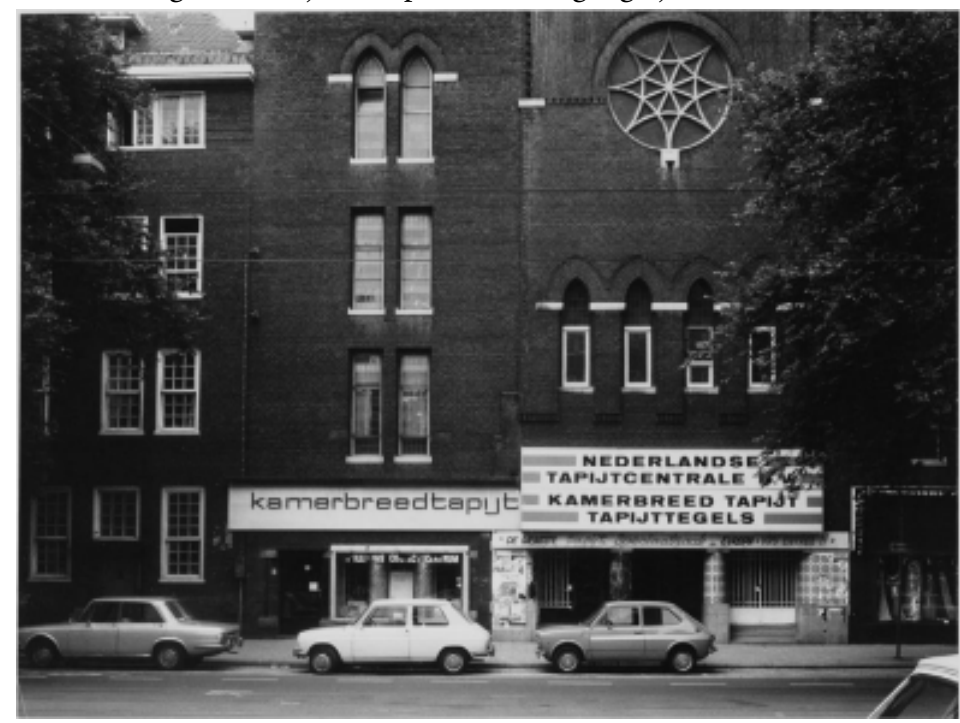

No letreiro acima da entrada se lê: "Central de Tapetes dos Países Baixos [...] a maior loja de tapetes da Europa - entrada livre!!”, 11 de julho de 1977. Fonte: Arquivo Municipal de Amsterdã. Fotografado por: J. M. Arsath Ro’is.

Um dos moradores da regiáo da mesquita recorda-se que por um determinado período depois de a The Sower ter sido convertida em mesquita, um pequeno grupo de católicos se reunia no lado de fora e rezava pela reconversão do edifício em igreja. Além de erigir um mirabe no lugar da antiga entrada da igreja (ver abaixo), os novos proprietários fizeram poucas mudanças no edifício: cobriram o chão com um tapete de oraçôes e instalaram painéis redondos pequenos, mas legíveis, contendo os nomes do Profeta Maomé, dos seus companheiros e netos Hasan e Husayn, entre outros. Uma divisória vazada foi instalada a fim de separar o espaço de orações das mulheres, localizado onde costumava ser o altar, e uma pequena câmara foi criada no local onde era a sacristia para realizar o Wudu, abluçóes rituais. Os púlpitos, os vitrais e os símbolos íctis no teto foram deixados como estavam. No lado de fora, as cruzes das torres foram substituídas pelas Crescentes Islâmicas 
(a substituição teria sido realizada durante a noite para não chamar muita atenção, conforme nos foi comunicado).

Assim, de diversas formas, a conversão da The Sower na Mesquita de Fatih espelhou a conversão anterior do edifício socialista Constantia na igreja Jesuíta, que presidiu a The Sower no mesmo local. Em ambos os casos, a conversão tornou-se possível apesar das apreensóes dos usuários originais por meio de um estágio intermediário e, em ambos os casos, poucas mudanças foram realizadas no edifício, incluindo a cruz colocada sobre o teto de Constantia e as crescentes substituindo as cruzes na The Sower. A comunidade da mesquita enfrentou uma situação semelhante a dos jesuítas que converteram Constantia à medida que erigiam o seu próprio local de culto em um lugar que havia sido construído para outras finalidades. Conforme comenta o arquiteto Hugo Caron (2006), em um panfleto designado à captaçáo de recursos para a restauração da mesquita e a construção da nova entrada: "Sendo uma igreja e não uma mesquita, é necessário fazer alteraçôes. Esta antiga igreja nunca foi adequadamente adaptada para o seu novo uso como mesquita". Em geral, no entanto, os membros da Mesquita de Fatih nunca tomaram isso como um problema. Além disso, a transformação em mesquita conectava diversos elos de conversóes materiais: começando com Constantia, em 1890, depois The Sower, em 1663 e, por fim, The Holy Stead, em 1347.

\section{A MESQUITA “OCULTA”}

A Mesquita de Fatih foi a primeira grande mesquita em Amsterdã e é fonte de orgulho para a comunidade turco-holandesa. No início da década de 1980, quando a institucionalização do Islá estava ainda engatinhando e muitos muçulmanos holandeses ainda se reuniam em mesquitas improvisadas (Maussen, 2009), criar uma mesquita a partir de uma antiga igreja táo grande e central foi uma conquista. Esse sentimento de orgulho permaneceu através dos anos. Um jovem congregado da mesquita que veio à Amsterdá para estudar, por exemplo, disse para um de nós (Daan Beekers) que os 
amsterdáos turcos que ele conheceu frequentemente falavam da Mesquita de Fatih como um lugar especial que precisava ser visto. A primeira menção era sempre que o edifício já tinha sido uma igreja, ele relatou. O nome "Fatih", comum entre mesquitas turcas, já estava em uso quando a comunidade alugou temporariamente o espaço na outra antiga igreja (Capela Nieuwezijds). O nome se refere à Mesquita de Fatih de Istambul, construída pelo Sultão Otomano Mehmed II, conhecido como el-Fatih (o Conquistador), que conquistou Constantinopla em 1453. Um dos primeiros atos do Sultáo na cidade derrotada foi a conversão da Basílica de Santa Sofia em uma mesquita (Mansel, 1995, p. 1-2). É possível que os membros da comunidade não possuíssem a intençáo de mudar esse nome simbólico quando compraram a The Sower, mas é também plausível que eles o considerassem apropriado para sua igreja convertida.

$\mathrm{O}$ jovem congregado acima mencionado sugeriu ainda que, às vezes, sentia que o tom utilizado pelos mais velhos ao falar da conversão era de certa forma muito celebratório, mas, depois, elaborou o seu pensamento lembrando que o orgulho mencionado náo era "imperialista", mas "um orgulho cujo cerne é a responsabilidade como servos de Deus". A fim de esclarecer, citou o que se encontra no site da mesquita, que afirma que a compra da The Sower não foi somente possível através da iniciativa dos "anciãos turcos", mas também por "Vontade Divina".

O site relata a história de um antigo padre da The Sower que foi até a comunidade da mesquita dizendo que se sentia honrado de que o edifício estava, mais uma vez, servindo à religião. E pediu à congregação mulçumana para cuidar da sua comunidade, pois se o edifício perdesse o seu propósito religioso, ele "morreria de tristeza". Mehmet Yamali, o porta-voz da mesquita que era criança na época, negou qualquer conexão entre o nome e o edifício, salientando que o nome fora adotado quando a comunidade estava alugando temporariamente a outra igreja ${ }^{7}$. O orgulho

7 O uso de "Fatih" para um edifício religioso convertido não é exclusivo desta mesquita: em 1979, a sinagoga em The Hague, que náo conseguiu se manter depois da Segunda

Debates do NER, Porto Alegre, ano I9, N. 34, P. I83-222, Ago./Dez. 20 i 8 
que os amsterdãos turcos sentem pela Mesquita de Fatih contrasta com a discrição da mesquita. Com exceção das luas crescentes nas torres, quase imperceptíveis, a comunidade até pouco tempo não havia exibido qualquer sinal claro que denotasse a identidade do edifício e nem construído uma entrada característica que combinasse com a grandeza da mesquita. Em parte, esse foi o resultado não intencional da divergência entre a estrutura do edifício da igreja e a organização do espaço sagrado para o islamismo. A qibla, direção específica da oração, que aponta para Mecca, era oposta à que os frequentadores católicos do edifício utilizavam nas suas oraçôes, não apontava para o antigo altar da igreja, mas para o outro lado, a antiga entrada. Com isso, a comunidade da mesquita decidiu construir o mirabe frente à entrada (Figura 6).

Guerra Mundial e ficou abandonada, foi ocupada e convertida por "migrantes trabalhistas" turcos. Quando perguntaram a um dos ancióes a respeito desse período, em um documentário de 2012 (Aurangzeb, N. 2012. Met het gezicht naar het oosten - de frente para o Leste. Hilversum: NTR), ele disse que, primeiro, "nomeamos a mesquita Fatih porque havíamos ocupado o edifício”. Em 1981, eles a renomearam de Aksa Mosque. O ancião explicou: "Os Judeus haviam [tomado] a Aksa Mosque [de Jerusalém]... então, nomeamos esta sinagoga, na Holanda, de Mesquita de Aksa”. As pessoas que atualmente trabalham na Mesquita de Fatih tendem a evitar essa linguagem de confronto, e Mehmet Yamali comentou que, provavelmente, teria escolhido outro nome. Quando Pooyan Tamimi Arab sugeriu-lhe que o nome não combinava com as atividades de alcance intercultural e inter-religioso, ele contrapôs que mudar o nome significaria se render às pressóes sociais holandesas exercidas sobre as mesquitas: "Eles [holandeses não-muçulmanos] ficariam ainda mais felizes se fechássemos”.

Debates do NER, Porto Alegre, ANo I9, N. 34, P. I83-222, Ago./Dez. 20 i 8 
Figura 6: Interior da Mesquita de Fatih durante as oraçôes de sexta-feira

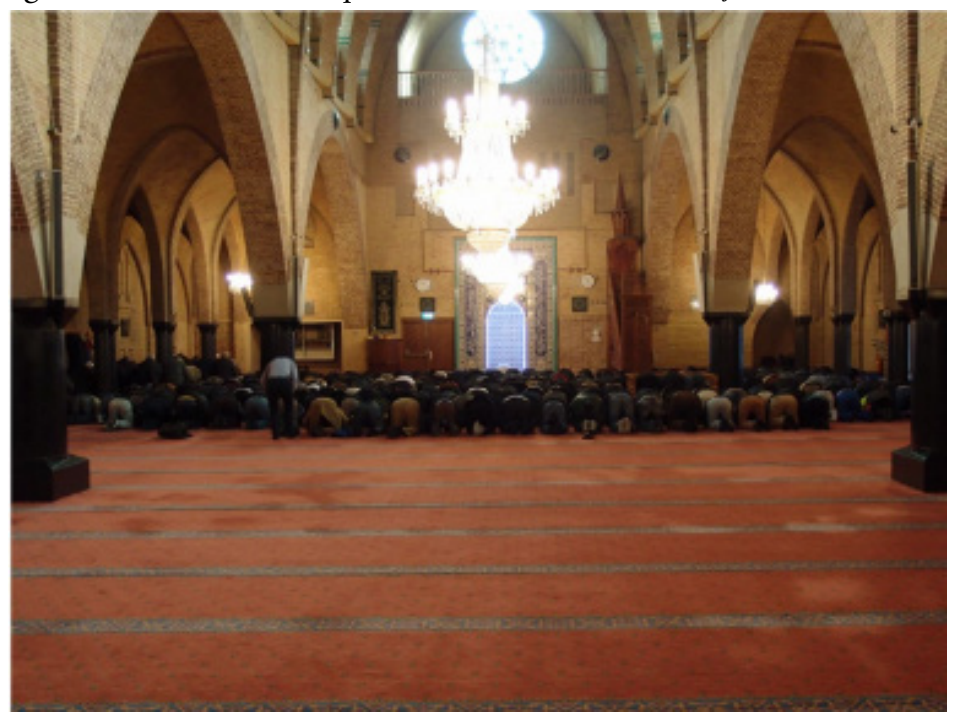

Fotografado por: Daan Beekers em 30 de outubro de 2015.

Uma pequena entrada e um hall sóbrio, que levam à sala de oraçóes, foram construídos ao lado da antiga igreja e a antiga entrada do templo deu lugar a lojas. Nesse sentido, a mesquita perdeu a entrada proeminente do edifício, que ficou discretamente localizada atrás de uma fileira de lojas, e a fachada da igreja. Um dos resultados é que grande parte dos moradores de Amsterdã não conhecem a mesquita. Muitos de nossos amigos, colegas e contatos de trabalho de campo da cidade, a quem perguntamos sobre a mesquita, desconheciam a existência da mesma e, em geral, nem haviam percebido o edifício monumental do local, mesmo sendo a maior mesquita da cidade, localizada na movimentada Rozengracht por mais de trinta anos. As pessoas que visitam a mesquita geralmente se surpreendem com a sua relativa invisibilidade, o que é ilustrado em um episódio de "Mijn moskee is top" (Minha mesquita é sensacional) sobre a Mesquita de Fatih, em um programa televisivo sobre mesquitas transmitido na Holanda entre 2011 e 2012. Nesse episódio, a apresentadora Samira el Kandoussi foi filmada tentando entrar na mesquita 
utilizando sua antiga entrada, mas onde, surpreendentemente, havia um saláo de beleza na época (e, atualmente, uma loja de bicicletas). Depois de cumprimentar o atendente iraniano da loja com um "salaam aleikum", ele a informou que a entrada da mesquita era a porta branca próxima ao edifício da igreja. $\mathrm{Na}$ época, as paredes estavam cobertas de grafites e os letreiros de um restaurante de grelhados e de uma padaria, adjacentes à entrada, dificultavam ainda mais a visibilidade da entrada da mesquita. Ao encontrar a entrada e passar pelo hall longo e estreito, Samira exprimiu um sentimento de reverência quando entrou no local de oraçôes, a antiga nave do templo católico : "ah, mashallah ["Deus desejou isso", uma frase comum em Árabe que expressa exaltação ou apreciação], é realmente bonito aqui”, ela exclamou.

Essa dupla experiência de perceber a discrição da mesquita do lado de fora e de deslumbramento no seu interior parece ser comum entre as pessoas que visitam o edifício. A discrição da mesquita também foi observada por um dos nossos interlocutores que, por muitos anos, havia sido membro do conselho da cidade de Amsterdã ocidental pelos Democratas Cristãos e também havia experimentado o fechamento de três igrejas da sua própria congregação Protestante Reformista. Certa vez, ele esteve na Mesquita de Fatih para uma reunião e apontou ter ficado surpreso quando chegou em frente ao edifício e não havia qualquer sinal que indicasse tratar-se de uma mesquita, nem uma inscrição. Para ele, parecia uma espécie de "schuilkerk", uma igreja oculta. Isso é o que o uso do termo schuilkerk diz, referindo-se às igrejas clandestinas católicas e protestantes não-calvinistas da República Holandesa.

Na Holanda, as noções de "ocultação" sempre têm sido utilizadas em discussóes a respeito de mesquitas. Pesquisadores, jornalistas e arquitetos frequentemente argumentam que, até os anos 2000, a existência de comunidades muçulmanas no país havia sido enormemente "ocultada". Tipicamente, esse argumento é ilustrado citando a predominância de mesquitas localizadas em edifícios já construídos e que, de maneira geral, não são prontamente reconhecíveis pela fachada (por exemplo, Erkoçu; Bugdaci, 2009; Maussen, 2009, p. 21; Sunier 2009, 
p. 171) ${ }^{8}$. O termo schuilmoskeeën, "mesquitas ocultas", vem sendo ocasionalmente empregado nessas discussões, referindo-se, de forma implícita ou explícita, às "igrejas ocultas" do passado. Nosso interlocutor acima citado deixou clara essa conexão ao descrever a Mesquita de Fatih não como uma "mesquita oculta", mas, devido a sua aparência de igreja, de "igreja oculta”.

Igrejas "ocultas", ou clandestinas, possuem a fama (ou a má fama) de exemplificarem a estratégia política de lidar com a diversidade religiosa na República Holandesa oficialmente calvinista. Igrejas católicas e protestantes não-calvinistas foram banidas, mas, na prática, toleradas, contanto que permanecessem fora das vistas do público (Kaplan, 2002, p. 1034). Benjamin Kaplan argumenta que as igrejas clandestinas, das quais pelo menos 30 haviam só em Amsterdã em 1700, desempenharam um papel importante no gerenciamento entre a devoção pública e privada: "Ao controlar a dissidência religiosa em espaços demarcados como privados, as schuilkerken preservaram o monopólio de uma igreja oficial para a comunidade na esfera pública” (2002, p. 1036).

Hoje, geralmente compreende-se que as igrejas clandestinas pertençam a um passado em que as religióes não dispunham de direitos iguais pela lei. A famosa igreja oculta transformada em museu, Ons' Lieve Heer op Solder (Nosso Senhor nas Alturas), em Amsterdã, ilustra o modo com que das casas de devoção clandestinas são hoje historicamente apresentadas como parte da herança cultural holandesa. Essa história, tão bem conhecida, significa que o conceito de "igreja oculta" logo surge como uma metáfora para descrever os locais de devoção atuais que não são identificáveis como tal do lado de fora, ou o são parcamente, como é o caso de diversas mesquitas.

Ainda assim, as chamadas "mesquitas ocultas" diferenciam-se de forma importante das igrejas clandestinas do passado: sua "ocultação" não resulta de arranjos legais que restringem a presença pública de determinadas comunidades religiosas, mas sim de fatores sócio-econômicos e antigas expectativas tanto do governo da Holanda quanto de migrantes muçulmanos, cuja

8 Discussões semelhantes podem ser encontradas fora da Holanda (por exemplo, Schuller, 2013). 
permanência no país seria temporária. O que conecta esses diversos usos, entretanto, é a noção de que uma casa de devoção "oculta" funciona como um gênero discursivo que denota a falta de existência pública de uma comunidade religiosa, uma situação vista como indesejável. De forma reveladora, o termo schuilkerken somente começou a ser empregado no século XIX, quando os católicos adotaram-no para enfatizar - e, de certa forma, exagerar - a opressão dos seus ancestrais (Dudok Van Heel, 1993).

Tais conotaçóes normativas refletem-se claramente nos usos atuais do termo "mesquitas ocultas", que geralmente vêm com a sugestão de que locais de devoção não deveriam se ocultar da visão das pessoas. Um bom exemplo do modo em que o termo é empregado nos debates sobre as mesquitas contemporâneas está em uma discussão ocorrida há alguns anos sobre o design da chamada Polder Mosque (Mesquita Polder). Enquanto sua arquitetura a apresenta como uma alternativa contemporânea de heimweemoskeeën (mesquitas nostálgicas), caracterizadas pelos minaretes e cúpulas convencionais, seus opositores supostamente a rejeitam como uma schuilmoskee, pois, para eles, a mesquita parece um local de trabalho moderno 9 . Da mesma forma, diversos de nossos interlocutores de Amsterdã, muçulmanos e não muçulmanos, disseram que as mesquitas deveriam ser reconhecíveis como tal. Por exemplo, um dos vizinhos da mesquita, um homem turco-holandês que, nas suas palavras, costumava ser um "muçulmano devoto", mas que não é mais praticante, explicou por que ele considerava que a construção de uma nova entrada para a mesquita era um desenvolvimento positivo: "se você fosse uma mesquita, você também mostraria isso, não com uma mera portinha [como a que a mesquita costumava ter]. É uma questão de personalização [...]. Na Turquia, uma casa de Deus tem uma porta grande. Se você não tem, é como se você pensasse: 'ninguém nos vê, portanto, ninguém se incomoda conosco'”. Ou, na perspectiva do holandês não-muçulmano:

9 "Uít de tijd of juist bíj de tijd: Over koepel-, heimwee-, polder-, schuil- en kosmosmoskeeën" (De estilo antigo ou contemporâneo: sobre mesquitas abobadadas, nostálgicas, de polder, ocultas ou cósmicas), NRC Handelsblad, 24 de julho de 2009.

Debates do NER, Porto Alegre, ANo i9, N. 34, P. I83-222, Ago./DeZ. 20 i 8 
"Eu não os vejo, então eles não me incomodam”. E comparou a situação à dos homossexuais: "Trata-se de mostrar suas cores, mostrar quem você é".

Nosso interlocutor que comparou a Mesquita de Fatih a uma "igreja oculta" disse que, como político local, devia apoiar a construção da Mesquita Ocidental em Amsterdã, pois ela representa que os "muçulmanos não precisariam mais rezar em garagens e em outros lugares escondidos". Para ele, a construção de mesquitas reais é melhor que a conversão de igrejas em mesquitas, pois "uma igreja ou uma mesquita tem suas próprias características [iets eigens], as quais você confronta [quando se tenta converter uma na outra]. Aqui, o valor depositado no reconhecimento parece ser informado não apenas pelo apoio para a existência de mesquitas em espaço público, mas também deriva da posição básica de que a aparência externa de um edifício deve corresponder à sua "verdadeira" natureza.

Ironicamente, a The Sower, uma igreja icônica, construída pela comunidade jesuíta no apogeu da emancipação católica e que tem suas raízes em uma "igreja oculta", torna-se agora uma "mesquita oculta" aos olhos de muitos. A Mesquita de Fatih, então, não está conectada com a história das igrejas clandestinas apenas por associação, mas também pela presente história do seu edifício. Tanto o legado do local de devoção "oculto" como um gênero discursivo historicamente construído quanto o legado do edifício atual da Mesquita de Fatih reforçam sua aparência de "igreja oculta" e limitam as tentativas da comunidade de torná-la mais reconhecível.

\section{A ARTE DE ATRAIR PESSOAS A UMA MESQUITA}

Nos últimos anos, líderes da Mesquita de Fatih buscaram atenuar a invisibilidade da mesquita, aumentando o contato entre a comunidade muçulmana e as pessoas residentes do bairro, e também com aquelas mais distantes. Mehmet Yamali, que é guia turístico voluntário e porta-voz, teve um papel importante nesta ação. Ele se tornou o agente social mais influente da mesquita e tem um papel central nos esforços para dotar a mesquita 
com status icônico. Por essa razão, ele também tem sido um interlocutor fundamental na nossa pesquisa sobre criação de iconicidade na Mesquita de Fatih. Desde que começou a trabalhar na mesquita, em 2006, o templo teve um aumento de visitantes de diversas origens diferentes, semanalmente e diariamente. Estes visitantes incluem grupos de turistas vindos da Indonésia ou outros países muçulmanos que buscaram no Google Maps uma mesquita para suas oraçóes (salaat). Protestantes suíços já vieram admirar o edifício, oferecendo a Mehmet uma caixa de chocolates e suas desculpas pela proibição de minaretes na Suíça, em 2009. Crianças vão à mesquita com a escola para tarefas, por exemplo, ou adolescentes não-muçulmanos com perguntas como "as mulheres devem usar burca, de acordo com o islá?", Budistas já tiraram fotos com o imã da Mesquita de Fatih. A mesquita já foi visitada diversas vezes por vereadores, pelo prefeito de Amsterdã e organizaçóes interessadas em "diálogos inter-religiosos". Devemos lembrar, ainda, os muitos pesquisadores acadêmicos, inclusive nós, que vão à Mesquita de Fatih.

A "oculta" Mesquita de Fatih prosperou e se tornou um local de interesse público (similar às "igrejas ocultas" do passado), e isso é em parte devido a sua natureza muito discreta de mesquita em um edifício de igreja. Ainda assim, se tornou significativamente menos "oculta" nos últimos dez anos. Mehmet inclusive disse que, para ele, os visitantes não-muçulmanos no local de oração são mais importantes que os congregados da mesquita. Em geral, esses visitantes não-muçulmanos têm pouca interação com eles e muitos são surpreendidos com o efeito "uau" causado pelo interior do edifício. Como Birgit Meyer (2015) argumenta, referindo-se à gênese de sensações de reverência ou perplexidade, que artefatos religiosos como edifícios frequentemente são muito mais que meras representaçóes. Na sua interação com sensaçóes corporais, esses artefatos religiosos podem "causar no público um aumento de sacralidade de maneira mais ou menos poderosa e persuasiva" (2015, p. 20). Pode-se dizer que, de certa forma, ao permitir a entrada de visitantes no local de oraçóes da mesquita, é mais a estética do edifício que a interação direta com "muçulmanos" que produz o efeito do encontro "interreligioso" ou "intercultural". 
Além de Mehmet, como porta-voz da mesquita, seu amigo e artista Jaap Kapteyn também desempenhou um papel importante em levar nãomuçulmanos para dentro da mesquita. Jaap morava na rua de trás do templo desde 1982. No início, ele nunca ia na mesquita, "ela era vista como um lugar um tanto estranho onde as pessoas não iam". Mesmo assim, depois, ele foi se envolvendo cada vez mais com o local decidiu ajudar a comunidade, nas suas palavras, se "emancipar" e abrir a mesquita para nãomuçulmanos. "Circula em nossa sociedade um veneno perigoso, um veneno que eu quero extinguir", ele disse, referindo-se à intolerância religiosa na Holanda, principalmente em relação aos muçulmanos. Por outro lado, ele também acredita que Mehmet e outros congregados da mesquita ainda se prendem nas categorias "nós" e "eles". Durante a organização de eventos públicos que levaram náo-muçulmanos à mesquita, ele se esforçou para atenuar o medo mútuo do "outro"10.

Com isso, Jaap convenceu os organizadores de uma rota artística chamada "Ateliers Abertos em De Jordaan" a incluírem também a mesquita. A rota, localizada no distrito central de Amsterdá, De Jordaan, ocorre a cada dois anos e permite que o público visite as galerias de arte e, inclusive, veja as obras nas casas dos artistas da vizinhança. Desde 2008, a mesquita participa do evento ${ }^{11}$. Jaap acreditava que, ao levar artistas não-muçulmanos e suas obras para dentro da mesquita, um contrapeso crítico poderia ser oferecido quanto à divisão frequente nos debates holandeses entre o islã e a arte contemporânea, em que o primeiro quase sempre é percebido como estagnante e em contradição com a liberdade, e o segundo, associado com a expressão individual e a política progressista (conforme Van der Veer, 2006). Durante o evento, a entrada da mesquita se faz visível graças à sinalizaçáo

${ }^{10}$ Os efeitos positivos pretendidos do "contato", subestimados em diversos projetos de coesão social, foram examinados de forma crítica por Gill Valentine (2008).

11 Veja, por exemplo, "Moskee opent deuren voor kunst" (A Mesquita abre as portas para a arte). Het Parool, 13 de maio de 2008. 
do programa Ateliers Abertos de De Jordaan, que indica aos milhares de visitantes que aquele também é um dos locais em que podem entrar e ver arte.

De acordo com Mehmet, a Secretaria de Relaçóes Religiosas da Turquia (Diyanet) ${ }^{12}$, atualmente sediada em Ankara, levou a sério a colaboração: quando os líderes da mesquita viram que seus superiores da Diyanet consideraram importante o projeto artístico, pois mais pessoas visitariam a mesquita, eles disseram que seguiriam fazendo isso neste momento, em que o desejo por uma entrada maior se tornou mais forte, e as pessoas que visitam a mesquita dizem que nem sabiam que ela estava lá. Dentre os programas de maior sucesso da Mesquita de Fatih está uma peça teatral inter-religiosa que ocorre no local de oração. Jaap e Mehmet enfatizaram o quão especial foi ter uma peça no local de oração, já que ela também incluía música, considerada não-islâmica por alguns congregantes, e leituras das Sagradas Escrituras cristã e judaica. Usar a arte contemporânea dentro dos edifícios da igreja para chamar atenção aos espaços da mesquita também já foi feito em outras cidades europeias, como em Veneza, em 2015, onde um artista converteu a Santa Maria, Mãe de Misericórdia em uma mesquita. Funcionários municipais, policiais e membros da Igreja Católica protestaram, os membros católicos alegando que a igreja, fechada por mais de quarenta anos, não havia sido desconsagrada oficialmente.

Um porta-voz islâmico foi citado pelo New York Times, dizendo "Às vezes você precisa se mostrar, mostrar que você é pacífico e que você quer que outras pessoas vejam a sua cultura.” Depois de apenas alguns encontros, a polícia fechou a "mesquita instalada", por ordem de funcionários municipais que rejeitaram a ideia de que um local artístico também poderia funcionar como um local de devoção islâmico ${ }^{13}$. Assim como a ideia de uma mesquita figurar em uma exposição artística foi considerada provocativa em Veneza,

12 Para mais informaçóes sobre o papel da Dyianet em assuntos religiosos de turcos pósmigrantes na Holanda e na Europa, ver Sunier e Landman (2015).

13 “Polícia fecha as instalações da mesquita na Bienal de Veneza." New York Times, 22 de maio de 2015. 
nem todos os membros da Mesquita de Fatih gostaram da ideia de haver arte em uma mesquita, principalmente se tratando da "deles": alguns dos congregados mais antigos reclamaram que as pinturas penduradas nas paredes do edifício eram blasfemas, já outros ficaram irritados pela perturbação dos negócios usuais. Com frequência, Mehmet fazia anedotas em relação à mentalidade "jurássica" deles: ele havia negociado persistentemente com os líderes da mesquita a respeito do quanto a mesquita poderia, por um lado, funcionar como um local capaz de impressionar não-muçulmanos e, por outro, como um espaço confortável e familiar para aqueles que utilizam a mesquita diariamente ${ }^{14}$.

Mehmet, em concordância com seu amigo Jaap, quis mudar um pouco as coisas, e utilizar a mesquita com uma visão bem ampla de promoção do "diálogo inter-religioso". Para ele, a mesquita poderia desempenhar um papel crucial no combate ao medo predominante em relação aos muçulmanos, e também ao preconceito. Sua ideia para o edifício foi moldada pelos locais icônicos das redondezas, tais como a Casa Anne Frank, o Homomonumento e a Igreja Ocidental. O Homomonumento, por exemplo, lembra a perseguição a grupos LGBT e está localizado atrás da Igreja Ocidental, no canal utilizado pela Marcha do Orgulho Gay. Durante o evento, a bandeira do arco-íris fica pendurada na torre da igreja (Figura 7).

${ }^{14}$ Agradecemos a Oskar Verkaaik pela distinção entre espaço habitual e visão icônica. 
Figura 7: Bandeira do Orgulho Gay na Igreja Ocidental

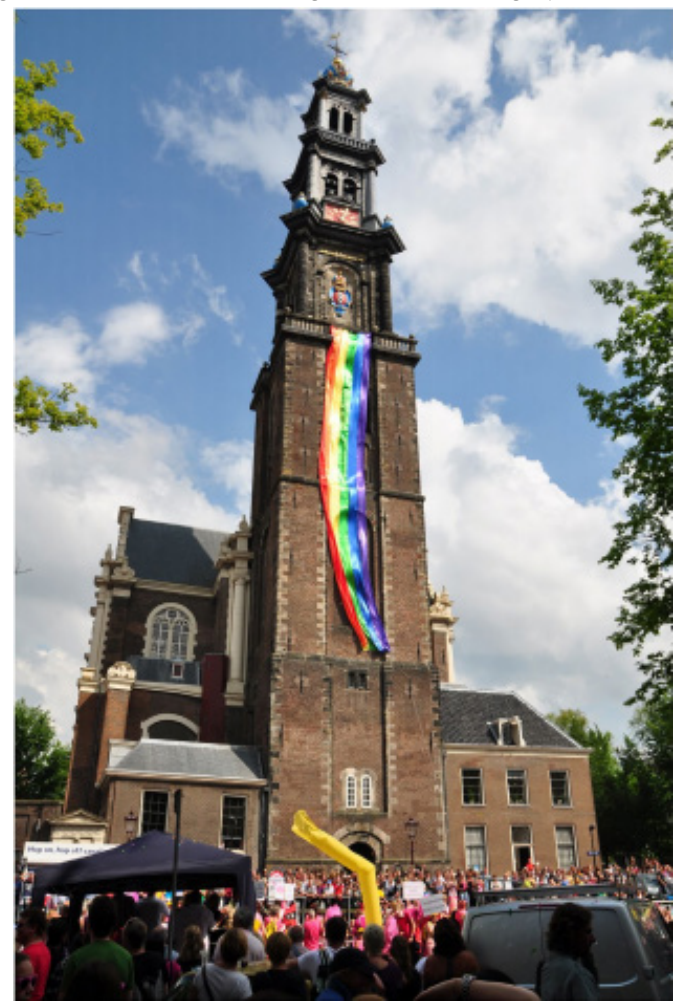

Fotografado por: Andrew Lee, em 4 de agosto de 2012.

Ao pensar que os muçulmanos e o islá também têm direito a uma presença pública tão explícita, Mehmet acredita que justamente a Mesquita de Fatih, devido a sua história sacra e localização, poderia desempenhar um papel importante no aumento da presença do público e na aceitação do islamismo. Essa posição não implica a aprovação de demonstraçóes públicas da homossexualidade. O próprio Mehmet descreve tais demonstraçôes, tanto de homossexualidade quanto de heterossexualidade, como "agressão sexual", embora diga que não iria tão longe a ponto de apoiar a proibição destas na Holanda, mas na Turquia, diz ele, seria diferente. Ainda assim, tanto o Homomonumento e a Igreja Ocidental desempenharam um papel central na

Debates do NER, Porto Alegre, ANo I9, N. 34, P. I83-222, Ago./Dez. 20 i 8 
sua visão de mesquita icônica: "Eu [a Mesquita de Fatih] não posso competir com a Igreja Ocidental, nem com o Homomonumento", ele disse. "A Igreja Ocidental tem o mistério da tumba de Rembrandt: ele foi enterrado lá, mas onde está o túmulo? Já o nosso edifício não tem nada parecido, nem com o Homomonumento, que divulga Amsterdã como uma capital gay [com o primeiro monumento gay do mundo]". Por outro lado, a proximidade da Casa Anne Frank e da Igreja Ocidental poderia ser aproveitada para aumentar o status público da mesquita: "se pudéssemos atrair uma pequena parcela dos visitantes da Casa Anne Frank ou da Igreja Ocidental [isto é, turistas, na sua maioria] em uma visita guiada mostrando as três religióes, o judaísmo [representado, para Mehmet, pela Casa Anne Frank], o cristianismo e o islá, então, realmente seríamos visíveis". Tais estratégias devem ser vistas como parte das práticas atuais, simultâneas e transnacionais que visam combater o preconceito anti-muçulmano. Para desempenhar o papel simbólico idealizado por Mehmet, o campo icônico com o qual edifícios como a Mesquita de Fatih estão relacionados tem um papel crucial.

Assim como em Nova Iorque, por exemplo, a proximidade do "local sacralizado" onde estavam as Torres Gêmeas permitiu que o Imã Abdul Rauf promovesse seu sonho de ter uma mesquita icônica pela paz mundial inter-religiosa (Rauf, 2012; revisto por Nussbaum, 2012). Na prática, entretanto, a mesquita também é utilizada de maneiras mais seculares, por exemplo, por funcionários muçulmanos de empresas como a American Express que simplesmente precisam de um local para rezar. Em relação a isso, o anseio por um edifício religioso icônico e cosmopolita pôde enfrentar a resistência dos usuários que não se identificavam com tais anseios icônicos e tinham mais interesse em preservar uma identidade étnico-religiosa ${ }^{15}$.

${ }^{15}$ Verkaaik (2014) igualmente descreve como uma comunidade russo-judaica procurou um espaço habitual e foi indiferente às celebradas memórias internacionais estéticas associadas à Nova Sinagoga de Dresden.

Debates do NER, Porto Alegre, ano I9, N. 34, P. I83-222, Ago./Dez. 20 i 8 


\section{O SURGIMENTO}

Mesmo que as atividades da mesquita tenham atraído, com sucesso, visitantes de todo tipo, ainda permanecia um sentimento de inadequação entre o papel conquistado de mesquita pública e acessível e a invisibilidade remanescente da mesquita. Essa sensação foi reforçada por comentários frequentes dos visitantes acerca da ausência de uma entrada proeminente. Assim, quando a mesquita organizou o iftar (a quebra do jejum) para não muçulmanos em 2008, uma política local que participou do evento comentou não ter conseguido encontrar a entrada e destacou que a mesquita deveria ter uma porta mais reconhecível. Mehmet disse que esse comentário "fomentou novamente toda a questão de uma porta maior". Modificaçôes estéticas foram realizadas prevendo uma nova entrada. Os grafites foram removidos das paredes e um grande letreiro foi fixado acima da entrada, a pedido de um oficial da Diyanet, no qual dizia claramente "Fatih Moskee" (Mesquita de Fatih) e "entree" (entrada). Ver Figura 8.

Figura 8: Entrada da Mesquita de Fatih

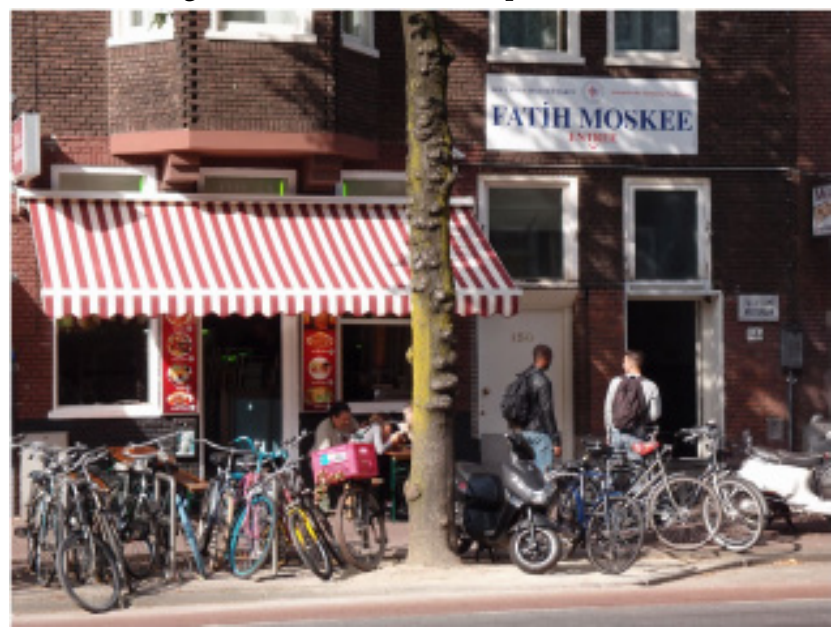

Fotografada por Daan Beekers, em 22 de setembro de 2014. 
A mesquita nunca havia tido um letreiro assim nas últimas três décadas, mas a política visitante comunicou a Mehmet que uma entrada irreconhecível simplesmente "não funcionaria", e que uma placa da Diyanet deveria ser pendurada até que a renovação da entrada começasse. Os tempos mudaram: diversas mesquitas da Diyanet foram construídas, já outras, como a Mesquita Aqsa, em Haia, que é uma sinagoga convertida, também haviam colocado recentemente letreiros claros e visíveis ${ }^{16}$. Os planos para uma nova entrada e saguão na Mesquita de Fatih estavam em açáo por mais de dez anos. Para Mehmet, esse foi um processo desafiador. Ele não apenas teve de lidar com o processo burocrático de mudar o exterior de um edifício tombado como monumento histórico, mas também enfrentar, junto com os outros apoiadores da nova entrada, a oposiçáo de parte da comunidade da mesquita.

De acordo com Mehmet, esses congregados viam a entrada como um local prático, nada além de um meio de chegar no local de oração: [Agora] eles estấo felizes [com os planos para uma nova entrada], mas também percebi que não tinham consciência do quáo feia era a nossa entrada... Olhe essa porta! [Eu lhes disse] Olhem a da Igreja Ocidental! Vocês não têm vergonha do nosso edifício? Da sua entrada? Eles [não-muçulmanos] são gentis com vocês - eu digo isso com frequência - mas sabem o que eles estáo pensando? Eles são turcos, esses muçulmanos: essa bagunça [rotzooi $]$ é parte do que eles

${ }^{16}$ Não somente as mesquitas na Holanda se tornaram mais visíveis recentemente, mas elas ampliaram significativamente os chamados para oraçôes, ou Adhan. Ampliar o Adhan é um direito garantido pela Constituição de 1983 e pelo Ato Público de Manifestaçóes que oficialmente entrou em efeito em 1988 (próxima publicação de Tamimi Arab). A Mesquita de Fatih, entretanto, se manteve em silêncio por décadas, em contraste aos sinos musicais da vizinha Igreja Ocidental, que podem ser ouvidos a cada 15 minutos para indicar as horas, todo dia e noite, mas também para chamar para oraçóes aos domingos pela manhã e durante eventos nacionais importantes, como a comemoração do final da Segunda Guerra Mundial. Mehmet Yamali por muito tempo não demonstrou interesse em ampliar o Adhan, em parte porque ele temia que isso atrairia uma atenção negativa da mídia e possivelmente atrasaria o projeto de renovação, mas ele e outros líderes da mesquita recentemente começaram a ponderar essa opção.

Debates do NER, Porto Alegre, ano I9, N. 34, P. I83-222, Ago./Dez. 20 i 8 
são, caóticos, desorganizados. Hoje, os congregados em geral concordam que uma nova entrada irá deixar a mesquita mais reconhecível. A entrada é, nas palavras de Mehmet, o "cartão de visita".

Além da Igreja Ocidental, comparando a futura nova entrada renovada da mesquita com a Casa Anne Frank e o Homomonumento, Mehmet a coloca em um campo icônico que inclui um conjunto de locais emblemáticos que são símbolos importantes em relação às narrativas dominantes sobre a identidade holandesa. Além disso, esses dois lugares se referem a grupos que, até então, tinham sido oprimidos e ocultados, mas que agora estão amplamente incorporados como parte crucial da nação holandesa ${ }^{17}$.

O que Mehmet estava dizendo, talvez de forma implícita, fosse que sua mesquita também precisava deixar o passado de "mesquita oculta" para trás e "surgir" como mesquita na esperança de ser aceita como parte da nação ${ }^{18}$. Entretanto, ele não parecia estar completamente confiante sobre este cenário: uma vez ele disse que "quando a entrada estiver pronta, veremos o que as pessoas realmente pensam de nós”. Antes que a construção da nova entrada pudesse começar, a comissão municipal encarregada do ambiente urbano e monumentos (Commissie voor Welstand en Monumenten) teve de ser convencida da necessidade de uma entrada nova, maior e mais reconhecível.

No início dos anos 2000, o arquiteto Hugo Caron, na época contratado pela mesquita, sugeriu ao conselho do templo que um plano geral para restaurar o edifício, assim como de renovar a entrada, ajudaria a persuadir a comissão (cujos conselhos geralmente são seguidos pela Câmara Municipal de Amsterdã). Uma comparação dos relatórios de inspeção do estado do edifício mostra que apesar de em 2002 ainda haverem muitos problemas maiores, como o vazamento no teto, tendo baldes no local de oraçáo para conter a água, em 2014 o edifício já havia sido restaurado em grande

${ }^{17}$ Justus Uitermark, Paul Mepschen, e Jan Willem Duyvendak (2015) analisaram o despertar do nacionalismo sexual na Holanda, no qual os direitos LGBT, identificados como valor nacional, são confrontados com os costumes sexuais conservadores associados aos muçulmanos.

${ }^{18}$ Agradecemos a Irena Stengs e a Jojada Verrips por pensarem nesta analogia.

Debates do NER, Porto Alegre, ano i9, N. 34, P. I83-222, Ago./Dez. 20 I 8 
parte $^{19}$. Enquanto que, no início dos anos 2000, o exterior do prédio era marrom e as torres tinham manchas pretas, a restauração deixou novamente visível o vermelho dos tijolos. Tais procedimentos foram caros, é claro, e a mesquita teve de economizar por alguns anos antes que uma nova entrada também pudesse ser construída. A comissão municipal rejeitou diversas propostas para uma nova entrada, entre elas, a de um projeto que incluía grandes portas de vidro e outro que sugeria adicionar um arco românico acima da nova entrada. Planos para criar uma entrada maior, com três portas, também foram descartados. $\mathrm{O}$ conselho da mesquita, por sua vez, não estava satisfeito com as sugestóes de somente renovar a porta ao invés de criar uma entrada maior.

Quando Mehmet e o segundo de quatro arquitetos envolvidos consecutivamente, Pieter Kok, debateram o assunto com a comissão municipal, foram comunicados de que a comissão não via "necessidade" de uma entrada maior. Mas quando Mehmet argumentou que em sextas-feiras de muito movimento a mesquita tinha centenas de visitantes e que a estreita entrada atual não era segura em caso de incêndio, o presidente da comissão foi convencido do plano de ampliar a porta e o corredor da entrada. Em uma carta para a Câmara Municipal (datada de 10 de novembro de 2010), a comissão escreveu: "Devido ao grande número de visitantes, o desejo de alterar a entrada é compreensível. [A comissão] também tornou possível, graças à função do edifício, criar um realce claro do lado de fora para que a entrada da mesquita seja reconhecida. Foi indicado que a provável nova entrada deveria se relacionar apropriadamente com a fachada como um todo".

Apesar desse resultado positivo, ainda levaram muitos anos até que algum projeto fosse aprovado. A escolha final pelo arquiteto Ergün Erkoçu, conhecido pelo projeto da Mesquita de Polder (por exemplo, Welzbacher 2008), revela o anseio de que fosse uma mesquita "moderna" e "aberta", igualmente "acessível” (laagdrempelig) para todos os muçulmanos e não-muçulmanos,

${ }^{19}$ Os relatórios foram feitos pela Monumentenwacht Noord Holland, uma organização independente que foi contratada pela mesquita. 
de acordo com Mehmet. Um dos colegas de Erkoçu envolvido no processo o descreveu como excepcionalmente "exigente" (moeizaam) e disse que o sucesso foi possível devido a uma abordagem "profissional", mais do que “emocional”. Na prática, isso significou seguir à risca as condiçôes burocráticas impostas pelo município, para que não houvesse a possibilidade de rejeição dos projetos. Mehmet suspirava frequentemente ao falar sobre o processo lento de alcançar todas as condiçóes para alterar um monumento patrimonial, e sentia que a importância da mesquita não era reconhecida pela comissão municipal. Enquanto que permitiram à nova loja da Apple de Amsterdã de fazer significantes mudanças no interior do monumental Edifício Hirsch na Praça Leidseplein, Mehmet escreveu a um ex-conselheiro municipal dizendo que a mesquita mal conseguia a aprovação para uma pequena mudança na entrada. Quando a renovação da entrada e do saguão começou, em 2015, foi um alívio imenso para Mehmet e os outros membros da comunidade envolvidos no projeto.

\section{CONCLUSÃO}

Numa sexta-feira à tarde, em dezembro de 2015, a Mesquita de Fatih estava viva com atividades. Os novos ladrilhos para o saguão acabavam de ser entregues e um grupo de homens trabalhava para levá-los ao interior. Os ladrilhos eram feitos de pedras ornamentais, explicou Mehmet, em um tom que sugeria que ele não se contentaria com menos. Com a hora da oraçáo de sexta se aproximando, jovens e velhos estavam tomando os seus lugares. Muitos olhavam os ladrilhos com aprovação, empilhados no corredor central da mesquita, alguns inclusive tocando-os para verificar sua qualidade. Olhando para a velha máquina de café ao lado das pilhas de ladrilhos, Mehmet comentou: "Também vamos pegar uma nova máquina de café. Uma com grãos frescos!" Ele esperava que os “antigos” apreciassem isso, já que estavam acostumados a beber café instantâneo barato. 
Os dois novos imãs da mesquita estavam parados. O mais novo dos dois foi o primeiro imã da Mesquita de Fatih a falar holandês fluentemente e a dar resumos de seus sermóes (khutab) de sexta-feira em holandês. Agora, ele geralmente fica encarregado das visitas guiadas que Mehmet costumava dar. Neste meio tempo, todos os ladrilhos foram trazidos pela porta temporária da entrada ampliada. As novas portas de madeira decorada seriam encomendadas logo, disse Mehmet. Como a oração da sexta-feira já iria começar, a Rozengracht do lado de fora da mesquita testemunhou o movimento cotidiano da vida da cidade, assim como em outra tarde qualquer, enquanto que, ao longe, os sinos da Igreja Ocidental começavam a badalar a hora. A construção de uma nova entrada é, ao menos por enquanto, o objetivo final da renovação da Mesquita de Fatih, que iniciou com a restauração necessária do velho edifício da igreja. A preparação e a construção da nova entrada foram delineadas em uma série de interaçóes com diversas circunstâncias, atores e anseios, inclusive as limitaçôes que o edifício eclesiástico impunha sobre o desejo crescente de visibilidade por parte dos líderes da mesquita, o legado de um gênero discursivo que enquadrou a mesquita como um local "oculto" de oração, políticos locais e outros visitantes que insistiram na necessidade de uma entrada mais visível, os esforços de Mehmet, Jaap e outros em levar não muçulmanos para dentro do templo e um desejo de relacionar-se a ícones próximos de Amsterdã, como a Igreja Ocidental e a Casa Anne Frank.

A reforma envolveu negociaçôes, dentro da comunidade muçulmana , entre os membros, na sua maioria jovens, que formularam projetos ambiciosos, e congregados, na sua maioria mais velhos, que estavam satisfeitos com seu local de oração habitual, da mesma forma que o estavam com seu café instantâneo. Por fim, como ficou claro, o desejo por uma mesquita de presença icônica na paisagem urbana foi o mais aclamado. Argumentamos que os anseios por uma iconicidade manifesta na Mesquita de Fatih deveriam ser compreendidos em relação às realidades materiais do edifício histórico, da história religiosa do local e do gênero discursivo de "ocultação", assim como dos locais icônicos com os quais a comunidade da mesquita se identifica. No caso dessa igreja convertida, localizada próxima a um ponto turístico 
badalado no centro de Amsterdá, expressa a inadequação em analisar locais de devoção isolados do seu entorno e em um único momento temporal. Em contraste, propusemos uma abordagem dos locais religiosos que atenta aos campos icônicos a eles associados, moldados por histórias locais e interaçóes contemporâneas com outros locais icônicos, tanto religiosos quanto não religiosos. Os esforços em criar iconicidade em um local como a Mesquita de Fatih não podem ser compreendidos de forma adequada se não formos atentos a seus entrelaçamentos no tempo e espaço.

\section{AGRADECIMENTOS}

Agradecemos a Steph Berns, Jaap Kapteyn, Kim Knott, Birgit Meyer e Oskar Verkaaik pelos seus comentários solícitos sobre o rascunho deste artigo. Versôes incipientes do mesmo foram apresentadas no Congresso Mundial da Associação Internacional de História das Religióes em 27 de agosto de 2015, e em uma reunião dos grupos de pesquisa de Estudos Religiosos e Islã \& Arábia na Universidade de Utrecht em 25 de novembro de 2015. Agradecemos ao público destes eventos pelos questionamentos e sugestóes. Também agradecemos a Mehmet Yamali e aos outros contatos que tivemos na Mesquita de Fatih pela sua cooperação e hospitalidade. A pesquisa de Daan Beekers para este artigo foi financiada pelo projeto de pesquisa em Religiáo Icônica da HERA. Pooyan Tamimi Arab foi auxiliado por uma bolsa de pós-doutorado do Departamento de Antropologia da Universidade de Amsterdã.

\section{FINANCIAMENTO}

O presente trabalho recebeu auxílio do Programa Coletivo de Pesquisa Encontros Culturais pela Humanidade na Área de Pesquisa Europeia (HERA) sob o contrato de financiamento número 235366/291827, e pela Universidade de Amsterdã. 


\section{REFERÊNCIAS}

BARTMANSKI, Dominik; ALEXANDER, Jeffrey. Materiality and meaning in social life: toward na iconic turn in cultural sociology. In: BARTMANSKI, Dominik; ALEXANDER, Jeffrey; GIESEN, Bernhard. (Ed.). Iconic Power: materiality and meaning in social life. New York: Palgrave Macmillan, 2012. p. 1-12.

BECCI, Irene; BURCHARDT, Marian; CASANOVA, José. (Ed.). Topographies of faith: religion in urban spaces (international studies in religion and society). Leiden: Brill, 2013.

BEEKERS, Daan. Precarious Piety: pursuits of faith among young muslims and christians in the Netherlands. Amsterdam: Vrije University Amsterdam, 2015. Originally apresented as a doctoral thesis, Vrije University Amsterdam, 2015. CARON, Hugo. The Fatih Mosque. Amsterdam: The Fatih Foundation, 2006. DECHAU, Wilfried. Mosques in Germany/Moscheen in Deutschland. Tübingen: Ernst Wasmuth Verlag, 2009.

DODSWORTH, Francis; VACCHELLI, Elena; WATSON, Sophie. Shifting Religions and Cultures in London's East End. Material Religion, Abingdon, v. 9, n. 1, p. 86-112, 2013.

DUDOK VAN HEEL, Sebastiaan. Amsterdamse Schuil- of Huiskerken? [Amsterdam's Hidden or House Churches?]. Holland, Holland, v. 25, p. 1-10, 1993.

ERKOÇU, Ergün; BUGDACÍ, Cihan (Ed.). The Mosque: Political, Architectural and Social Transformations. Rotterdam: NAi Uitgevers, 2009.

HAYDEN, Robert M.; WALKER, Timothy D. Intersecting Religioscapes: A Comparative Approach to Trajectories of Change, Scale, and Competitive Sharing of Religious Spaces. Journal of the American Academy of Religion, Oxford, v. 81. n. 2, p. 399-426, 2013. 
ISRAEL, Jonathan. The Dutch Republic: its rise, greatness and fall 1477-1806. Oxford: Clarendon Press, 1995.

KAPLAN, Benjamin. Fictions of Privacy: House Chapels and the Spatial Accommodation of Religious Dissent in Early Modern Europe. American Historical Review, Oxford, v. 107, n. 4, p. 1031-1064, 2002.

KERSHEN, Anne; VAUGHAN, Laura. "There Was a Priest, a Rabbi and an Imam ...": an analysis of urban space and religious practice in london's east end, 1685-2010. Material Religion, Abingdon, v. 9, n. 1, p. 10-35, 2013. KNOTT, Kim. The Location of Religion, a Spatial Analysis. London: Equinox Publishing, 2005.

KUPPINGER, Petra. Mosques and Minarets: Conflict, Participation, and Visibility in German Cities. Anthropological Quarterly, Baltimore, v. 87, n. 3, p. 793-818, 2014.

. Factories, Office Suites, Defunct and Marginal Spaces: Mosques in Stuttgart, Germany. In: GUGGENHEIM, Michael; SÖDERSTRÖM, Ola (Ed.). Reshaping Cities: How Global Mobility Transforms Architecture and Urban Form. London: Routledge, 2010. p. 83-99.

MANSEL, Philip. Constantinople: city of the world's desire, 1453-1924. London: John Murray, 1995.

MAUSSEN, Marcel. Constructing Mosques, the Governance of Islam in France and the Netherlands. 2009. Thesis (PhD Social Science) - Amsterdam School for Social Science Research, Amsterdam, 2009.

MEYER, Birgit. How to capture the 'wow': R.R. Marett's notion of awe and the study of religion. Journal of the Royal Anthropological Institute, Medford, v. 22 , n. 1, p. 7-26, 2015.

NUSSBAUM, Martha. The New Religious Intolerance: overcoming the politics of fear in an anxious age. Cambridge, MA: The Belknap Press of Harvard University Press, 2012. 
RAUF, Feisal. Moving the Mountain: a new vision of Islam in America. New York: Free Press, 2012.

ROOSE, Eric. The Architectural Representation of Islam: muslimcommissioned mosque design in the Netherlands. Amsterdam: ISIM; Amsterdam University Press, 2009.

SCHMITT, Thomas. Moscheen in Deutschland: konflikte um ihre errichtung und nutzung [Mosques in Germany: conflicts over their construction and use]. Flensburg: Deutsche Akademie für Landeskunde, 2003.

SCHULLER, Josef. Die Verborgene Moschee: zur sichtbarkeit muslimischer gebetsräume in Wien [The hidden mosque: on the visibility of muslim prayer spaces in Vienna]. Marburg: Tectum Verlag, 2013.

SUNIER, Thijl. Houses of worship and the politics of space in Amsterdam. In: NELL, Liza; RATH, Jan (Ed.). Ethnic Amsterdam: immigrants and urban change in the twentieth century. Amsterdam: Amsterdam University Press, 2009. p. 159-176.

SUNIER, Thijl; LANDMAN, Nico. Transnational Turkish Islam: shifting geographies of religious activism and community building in Turkey and Europe. Basingstoke: Palgrave Macmillan, 2015.

TAMIMI ARAB, Pooyan. The biggest mosque in Europe! A symmetrical anthropology of islamic architecture in Rotterdam. In: VERKAAIK, Oskar (Ed.). Religious Architecture: anthropological perspectives. Amsterdam: Amsterdam University Press, 2013. p. 47-61.

TANYERI-ERDEMIR, Tuğba; HAYDEN, Robert; ERDEMIR, Aykan. The Iconostasis in the Republican Mosque: transformed religious sites as artifacts of intersecting religioscapes. International Journal of Middle East Studies, Cambridge, v. 46, n. 3, p. 489-512, 2014.

TWEED, Thomas. Crossing and Dwelling: a theory of religion. Cambridge: Harvard University Press, 2006. 
UITERMARK, Justus; MEPSCHEN, Paul; DUYVENDAK, Jan Willem. Populism, sexual politics, and the exclusion of muslims in the Netherlands. In: BOWEN, John et al. European States and Their Muslim Citizens: the impact of institutions on perceptions and boundaries. Cambridge: Cambridge University Press, 2015. p. 235-255.

VALENTINE, Gill. Living with difference: reflections on geographies of encounter. Progress in Human Geography, Thousand Oaks, v. 32, n. 3, p. 321-335, 2008.

VAN DAEL SJ, Peter. 'Grootsch en doelmatig': negentiende- entwintigste-eeuwse jezuïetenkerken in Nederland, in het bijzonder De Krijtberg en De Zaaier in Amsterdam ['Magnificent and efficient': nineteenth and twentieth century jesuit churches in the Netherlands, in particular De Krijtberg and De Zaaier in Amsterdam]. In: VAN GENNIP, Joep; POELS, Vefie; WILLEMSEN, Marie-Antoinette (Ed.). Creatie en recreatie: cultuur en ontspanning in het kloosterleven [Creation and recreation: culture and recreation in monastery life]. Hilversum: Uitgeverij Verloren, 2014. p. 213-230.

VAN DER VEER, Peter. Pim Fortuyn, Theo Van Gogh, and the politics of tolerance in the Netherlands. Public Culture, New York, v. 18, n. 1, p. 111-124, 2006.

VAN EIJNATTEN, Joris, VAN LIEBURG, Fred. Nederländse Religie Geschiedenis [Dutch History of Religion]. Hilversum: Verloren, 2005.

VAN HAARLEM, Bisdom; ROTTERDAM, Bisdom; BELVEDERE, Projectbureau. Onderzoek herbestemming kerken en kerklocaties: een inventarisatie vanaf 1970 [Research into the repurposing of churches and church locations: an inventory from 1970]. Houten: Digital4, 2008.

VERKAAIK, Oskar. Designing the 'anti-mosque': identity, religion and affect in contemporary european mosque design. Social Anthropology, Hoboken, v. 20, n. 2, p. 161-176, 2012. 
.The Art of Imperfection: contemporary synagogues in Germany and the Netherlands. Journal of the Royal Anthropological Institute, Amsterdam, v. 20, n. 3, p. 486-504, 2014.

VON DER DUNK, Thomas H. 'Een prachtig tempelgebouw binnen de hoofdstad Des Rijks': de bouw van 'de Zaaier' aan de Amsterdamse Keizersgracht ['A splendid temple building within the capital of the State': the construction of 'de Zaaier' on Amsterdam's Keizersgracht]. Amstelodamum, Amsterdam, v. 88, n. 3, p. 1-15, 2001.

WELZBACHER, Christian. Euroislam-Architektur: Die Neuen Moscheen Des Abendlandes [Euro-Islam Architecture: the New Mosques of the Occident]. Amsterdam: SUN Architecture, 2008.

Recebido em: 01/02/2018

Aprovado em: 04/04/2018 